\title{
EFEKTIFITAS PROGRAM PENDISTRIBUSIAN DANA ZAKAT DI BADAN AMIL ZAKAT NASIONAL (BAZNAS) KOTA BOGOR
}

\section{EFFECTIVENESS OF DISTRIBUTION PROGRAM FUNDS IN BADAN AMIL ZAKAT NASIONAL (BAZNAS) BOGOR CITY}

\author{
A.Fadilah'; A. Sukma² \\ 1Program Studi Ekonomi Islam Fakultas Ekonomi Islam Universitas Djuanda, Jl. Tol Ciawi \\ No. 1, Kotak Pos 35 Bogor 16720 \\ 2Program Studi Perbankan Syariah Fakultas Ekonomi Islam Universitas Djuanda, Jl. Tol \\ Ciawi No. 1, Kotak Pos 35 Bogor 16720
}

\begin{abstract}
This research aims to determine the effectiveness of the program in the distribution of zakat funds in BAZNAS City of Bogor. The programs contained in BAZNAS city of Bogor such as Bogor Smart program, this is a distribution program that has the highest existence program. The number of respondents in this study were 30 respondents using Convenience Sampling. The Tehnique analysis that used was IPA. The results of the research have been effective based on the results if the data is to make use of analytical methods Customer statisfaction Index (CSI) and obtained yield was 75.63.
\end{abstract}

Keywords: Effectiveness, Zakat

\begin{abstract}
ABSTRAK
Penelitian ini bertujuan untuk mengetahui efektifitas program pendistribusian dana zakat di BAZNAS Kota Bogor. Dari program-program yang terdapat di BAZNAS Kota Bogor, program Bogor Cerdas merupakan program pendistribusian yang memiliki eksistensi program paling tinggi. Jumlah responden pada penelitian ini sebanyak 30 responden dengan menggunakan teknik Convenience Sampling. Hasil dari penelitian sudah efektif berdasarkan dari hasil olah data dengan menggunakan metode analisis Customer Statisfaction Index (CSI) dan diperoleh hasil sebesar 75,63.
\end{abstract}

Kata kunci: Efektifitas, Zakat

Fadilah, A. 2016 Efektifitas Program Pendistribusian Dana Zakat Di Badan Amil Zakat Nasional (BAZNAS) Kota Bogor. Jurnal Syarikah 2(2). Hal 279-295 


\section{PENDAHULUAN}

Salah satu permasalahan nyata yang di hadapi Indonesia adalah masalah kemiskinan. Kemiskinan di Indonesia lebih banyak terdapat pada daerah pedesaan. Pada bulan September 2014, di daerah perkotaan terdapat 10,36 juta jiwa orang miskin dengan persentasi 8,16 persen dan di daerah pedesaan terdapat 17,37 juta jiwa orang miskin dengan persentasi 13,76 persen. Di sisi lain, angka kemiskinan dari bulan September 2013 sampai bulan September 2014 mengalami penurunan baik di daerah perkotaan maupun pedesaan. Di daerah perkotaan mengalami penurunan dari 8,55 persen menjadi 8,16 persen dan di daerah pedesaan mengalami penurunan dari 14,37 persen menjadi 13,76 persen.

Namun demikian pemerintah terus berupaya menekan kenaikan angka kemiskinan melalui berbagai kebijakan, pemerintah akan menekan angka kemiskinan yang masih tinggi dengan dana sebesar Rp. 47,2 triliun. Akan tetapi, dilihat dari angka kemiskinan yang ada, angka tersebut masih sangat jauh dari kemungkinan untuk mengentaskan kemiskinan. Menurut Utami (2015: 8) jika dibandingkan dengan belanja modal di tahun 2015, jumlah ini naik 100 persen.

Di sisi lain Islam menawarkan konsep zakat sebagai program pengentasan kemiskinan dalam perekonomian Islam. Zakat sebagai bagian dari rukun Islam tidak hanya memiliki dimensi spiritual tetapi juga dimensi sosial. Zakat sebagai salah satu jaminan sosial kepada masyarakat terutama kepada golongan yang memerlukan, meningkatkan pertumbuhan ekonomi yang seimbang melalui kesadaran berzakat dalam masyarakat dan sebagai satu bentuk penyucian dan pembangunan rohani setiap Muslim (Pusat Zakat Melka, 2011).

Penghimpunan dana yang dilakukan oleh BAZNAS Kota Bogor cenderung berfluktuatif. Seperti pada tahun 2009 terhimpun dana sebesar Rp. 2.570.000.000,00 dan pada tahun 2010 mengalami kenaikan menjadi Rp. 2.730.000.000,00. Pada tahun 2011 dana yang dihimpun oleh BAZNAS Kota Bogor mengalami penurunan kembali di angka Rp. 2.680.000.000,00 dan pada 2 tahun berikutnya BAZNAS Kota Bogor berhasil meningkatkan penghimpunan dana zakatnya, yaitu pada tahun $2012 \mathrm{Rp}$. 2.810.000.000,00 dan pada tahun $2013 \mathrm{Rp}$. 3.320.000.000,00. Fluktuatifnya data penghimpunan dana zakat di atas menggambarkan ketidakpastian para muzakki yang membayar zakat sehingga dana zakat yang dihimpun oleh BAZNAS Kota Bogor pun tidak menentu pada setiap tahunnya. Karena ketidakpastian dana yang dihimpun oleh BAZNAS Kota Bogor, maka dari itu BAZNAS Kota Bogor mendistribusikan dana zakat yang ada untuk pemberdayaan dan pengembangan masyarakat dengan program-program yang telah dibuat oleh BAZNAS Kota Bogor. Upaya ini bertujuan untuk mengefektifitaskan dana zakat agar dapat didistribusikan secara maksimal dan produktif melalui program-program yang ada di BAZNAS Kota Bogor.

\section{MATERI DAN METODE}

\section{Jenis dan Objek Penelitian}

Jenis penelitian yang penulis gunakan dalam menganalisis efektifitas pendistribusian dana zakat di BAZNAS Kota Bogor ini merupakan penelitian yang menggunakan metode deskriptif kuantitatif. Penelitian Deskriptif merupakan dasar bagi semua penelitian. 
Penelitian deskriptif dapat dilakukan secara kuantitatif agar dapat dilakukan analisis statistik (Basuki, 2006: 110). Sehingga hanya akan memberikan gambaran secara umum atas fakta yang terjadi tanpa ada perlakuan atas hal yang akan diteliti. Objek dari penelitian ini adalah BAZNAS Kota Bogor. Alamat Jl. Pajajaran No. 10 Kelurahan Baranangsiang Kecamatan Bogor Timur Kota Bogor.

\section{Populasi dan Sampel}

Populasi adalah wilayah generalisasi yang terdiri atas subjek atau objek yang mempunyai kualitas dan karakteristik tertentu yang diterapkan oleh peneliti untuk dipelajari kemudian ditarik kesimpulan. Sedangkan sampel adalah suatu himpunan bagian (subset) dari unit populasi (Kuncoro, 2003:103). Sampel penelitian adalah bagian dari populasi yang dijadikan subyek. Populasi dari penelitian ini adalah karyawan BAZNAS Kota Bogor. Jumlah sampel yang digunakan adalah sebanyak 30 orang karyawan BAZNAS Kota Bogor. Teknik sampling yang digunakan adalah teknik convenience sampling. Convenience sampling adalah istilah umum yang mencakup variasi luasnya prosedur pemilihan responden. Convenience sampling berarti unit sampel yang ditarik mudah dihubungi, tidak menyusahkan, mudah untuk mengukur, dan bersifat kooperatif. (Abdul Hamid, 2007:30).

\section{Teknik Pengumpulan Data}

Teknik pengumpulan data yang digunakan dalam penelitian ini adalah dengan menggunakan kuisioner. Kuisioner adalah suatu cara mengumpulkan data dengan memberikan daftar pertanyaan pada responden dengan harapan mereka akan memberikan jawaban atas daftar pertanyaan tersebut. Dengan daftar pertanyaan bersifat tertutup yaitu dengan memberikan alternatif-alternatif jawaban yang telah disediakan (Husein, Umar, 2002:14).

Kuisioner menggunakan skala likert, skala ini berhubungan dengan pertanyaan tentang sikap seseorang terhadap sesuatu, misalnya setuju-tidak setuju, senang-tidak senang, baik-tidak baik (Husein, Umar, 2005: 89). Dengan menggunakan skala likert 5 poin. Skala ini digunakan dengan cara memberikan daftar pertanyaan pada responden, dengan menjawab berdasar tingkatan jawaban yang tersedia. Mulai dari sangat setuju, setuju, ragu-ragu, tidak setuju, sangat tidak setuju.

\section{Teknik Analisis Data}

Uji Validitas dan Reliabilitas

Uji Validitas digunakan untuk mengetahui kelayakan butir-butir dalam suatu daftar pertanyaan. Validitas mengukur sejauh mana suatu alat ukur itu mengukur apa yang ingin anda ukur. Sehingga dapat dikatakan mampu memperoleh data yang tepat dari variabel yang diteliti. Kriteria dari validitas yaitu bila koefisien kolerasi masing-masing pertanyaan dengan nilai Corrected Item Total Correlation lebih besar atau sama dengan $r$ tabel. Maka, instrumen dinyatakan valid.

Sedangkan reabilitas adalah suatu angka indeks yang menunjukkan konsistensi suatu alat ukur dalam mengukur suatu gejala yang sama. Setiap alat ukur seharusnya memberikan hasil pengukuran yang konsisten. (Umar, 2005: 135). Suatu variabel dikatakan reliabel jika nilai cronbach alpha lebih besar dari 0,6 (Ghazali, 2001: 42).

\section{Importance Performance Analysis (IPA)}

Importance Performance Analysis (IPA) adalah sebuah metode untuk memetakan tingkat kepentingan atas kinerja tertentu dari sebuah produk. 
Kemudian tingkat kepentingan tersebut dipetakan dalam diagram kartesius yang disebut Matriks IPA (Cahya, 2014: 48).

Menurut Basri (2011) analisis kuadran atau Importance Performance Analysis (IPA) merupakan teknik analisis deskriptif yang pertama kali diperkenalkan oleh John A. Martilla dan John C. James pada tahun 1977. Importance Performance Analysis adalah suatu teknik analisis yang digunakan untuk mengidentifikasi faktorfaktor kinerja penting apa yang harus ditunjukkan oleh suatu organisasi dalam memenuhi kepuasan para pengguna jasa (konsumen). Dalam penelitian ini, teknik Importance Performance Analysis (IPA) digunakan bertujuan untuk mengidentifikasi sejauh mana efektifitas program pendistribusian dana zakat di BAZNAS Kota Bogor, sehingga BAZNAS Kota Bogor dapat mengetahui seberapa besar efektifitas program-program pendayagunaan zakat dan dapat mengetahui strategi pendistribusian dana zakat yang efektif yang ada di BAZNAS Kota Bogor.

Analisis kuadran atau Importance Performance Analysis (IPA) ini mengaitkan antara tingkat kepentingan (importance) suatu atribut yang dimiliki obyek tertentu dengan kenyataan (performance) yang dirasakan oleh pengguna. Dalam penelitian ini, tingkat kepentingan (importance) yang ditujukan adalah program yang ada di BAZNAS Kota Bogor, sedangkan kenyataan (performance) adalah implementasi program pendistribusian dana zakat yang telah dilaksanakan oleh BAZNAS Kota Bogor. Dalam teknik IPA ini dapat dilakukan dengan menggabungkan faktor (klausul) pendistribusian dana zakat dan tingkat implementasi yang telah dilaksanakan dalam grafik dua dimensi yang memudahkan penjabaran data. Grafik
IPA dibagi menjadi empat buah kuadran berdasarkan hasil pengukuran Importance Performance Analysis sebagaimana terlihat pada gambar 1.

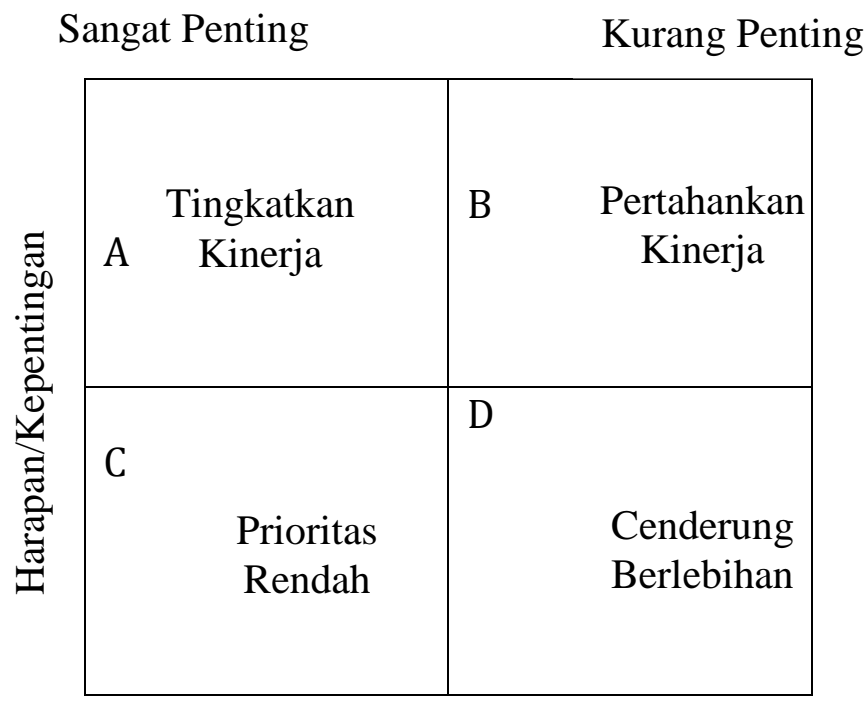

Rendah Persepsi/Kinerja Aktual Tinggi

Gambar 1. Diagram Kartesius

Dalam interpretasi kuadran (Supranto dalam cahya, 2014: 48-49), berikut dijelaskan masing-masing kuadran pada gambar 1.

Kuadran A, Tingkatkan Kinerja (high importance \& low performance)

Faktor-faktor yang terletak pada kuadran ini dianggap sebagai faktor yang sangat penting oleh BAZNAS Kota Bogor. Namun program pendistribusian dana zakat tersebut kurang dari yang diharapkan sehingga pihak manajemen pendistribusian dana zakat berkewajiban mendistribusikan dana zakatnya melalui program yang efektif untuk meningkatkan efektifitas pendistribusian dana zakatnya berbagai faktor tersebut. Faktor-faktor yang terletak pada kuadran ini merupakan prioritas untuk ditingkatkan.

\section{Kuadran B, Pertahankan Kinerja (high importance \& high performance)}

Faktor-faktor yang terletak pada kuadran ini dianggap sebagai faktor penunjang 
sehingga pihak manajemen pendistribusian dana zakat berkewajiban memastikan bahwa program pendstribusian dana zakat yang yang dikelolanya dapat terus mempertahankan efektifitas yang telah dicapai.

\section{Kuadran C, Prioritas Rendah (low importance \& low performance)}

Faktor-faktor yang terletak pada kuadran ini mempunyai tingkat kepentingan yang rendah dan sekaligus dianggap tidak perlu memprioritaskan atau terlalu memberikan perhatian pada faktor-faktor tersebut.

Kuadran D, Cenderung Berlebihan (low importance \& high performance)

Faktor-faktor yang terletak pada kuadran ini dianggap tidak terlalu penting sehingga pihak manajemen pendistribusian dana zakat perlu mendistribusikan dana zakatnya dari faktor-faktor tersebut kepada faktor-faktor lain yang mempunyai prioritas penanganan efektifitas pendistribusian program lebih tinggi yang masih membutuhkan peningkatan.

Rumus yang di gunakan dalam IPA adalah sebagai berikut:

$$
T k i=\frac{X i}{Y i}=X 100 \%
$$

Keterangan:

$\mathrm{TKi}=$ Tingkat kesesuaian responden

$$
\begin{aligned}
\mathrm{Xi}= & \text { Skor penelitian tingkat } \\
& \text { kinerja/kepuasan } \\
\mathrm{Yi}= & \text { Skor penilaian kepentingan }
\end{aligned}
$$

\section{Analisis Efektifitas Program} Pendistribusian Dana Zakat di BAZNAS Kota Bogor dengan Customer Statisfaction Index (CSI)

Metode analisis CSI ini bertujuan untuk mengukur dan mengetahui sejauh mana kepusan responden terhadap kinerja atau kenyataan yang telah dilakukan oleh BAZNAS Kota Bogor. CSI merupakan alat analisis yang bertujuan untuk mengetahui kepuasan responden. Analisis CSI ini dimulai dengan menentukan Mean Importance Score (MIS) dan Mean Satification Score (MSS). Cara untuk untuk menentukan CSI ini adalah sebagai berikut (Andi dalam Cahya, 2014: 50-51):MIS, didapatkan dari rata-rata, dari tingkat harapan dibagi dengan jumlah responden. MSS, didapatkan dari rata-rata, dari tingkat kenyataan atau kinerja dibagi dengan jumlah responden.WF, didapatkan dengan cara menghitung nilai MIS perfaktor dibagi dengan total MIS seluruh atribut. WS, didapatkan dari mengalikan WF dengan MSS.CSI, didapatkan dari menjumlahkan seluruh faktor WS atau disebut dengan WT dan membaginya dengan skala nominal 5 dikalikan $100 \%$.

Tabel 1. Kriteria Nilai CSI

\begin{tabular}{|l|l|l|}
\hline No. & Indeks CSI & Parameter \\
\hline 1 & $90,01-100 \%$ & Excellent \\
\hline 2 & $70,01-90,00 \%$ & Statisfied \\
\hline 3 & $50,01-70,00 \%$ & Average \\
\hline 4 & $25,01-50,00 \%$ & Unstatisfied \\
\hline 5 & $0-25,00 \%$ & Very Unstatisfied \\
\hline
\end{tabular}

Sumber: Ariestonandri dalam Cahya, 2014: 51

\section{HASIL DAN PEMBAHASAN}

\section{Program Pendistribusian Bogor Cerdas BAZNAS Kota Bogor}

Pendidikan menjadikan manusia memperoleh kehidupan yang lebih baik "education for a better life". Dimana kehidupan yang sesuai dengan kodratnya sebagai manusia dan hamba Allah SWT. Setiap manusia yang dilahirkan di dunia ini sebagai seorang khalifah, pemimpin bagi dirinya, keluarga, masyarakat dan makhluk lain yang ada di muka bumi. Sehingga kemunculan manusia bisa menjadi rahmat semesta alam.

Kehidupan yang baik tidak hanya dilihat dari sisi materinya saja, kepintarannya saja maupun ruhaninya saja. Kehidupan yang baik akan terjadi bila seseorang bisa berbagi dengan harta yang 
dimilikinya, mengajarkan ilmu yang didapatnya serta mengajak orang untuk taat kepada sang pencipta manusia. Potensi yang tidak pernah Allah berikan kepada makhluk lain, yaitu karunia akal dan pikiran dapat menghasilkan kemanfaatan yang tinggi bila dikelola secara optimal. Namun, kemampuan manusia dalam menggunakan akal dan pikirannya berbeda-beda, tergantung sampai mana manusia tersebut ingin mengeksplor kemampuan akalnya untuk berpikir. Oleh karena itu Allah mewajibkan kepada hambanya untuk belajar demi meningkatkan dan lebih mengeksplor lagi potensi yang telah Allah berikan.

Pada kenyataannya banyak masyarakat khususnya di Kota Bogor yang terhambat dan tidak dapat belajar karena biaya pendidikan yang sangat tinggi. BAZNAS Kota Bogor mempunyai program pendayagunaan dana ZIS di dalam dunia pendidikan guna membantu para masyarakat dhuafa untuk dapat terus belajar demi meningkatkan kemampuan dirinya sehingga memiliki daya saing (Laporan BAZNAS Kota Bogor, 2010: 4344).

Tujuan dari program Bogor Cerdas ini ada dua yaitu tujuan umum dan tujuan khusus. Tujuan umum dari program Bogor Cerdas adalah meningkatkan derajat pendidikan masyarakat dhuafa kota Bogor. Adapun tujuan khusus dari program Bogor Cerdas adalah pertama untuk membantu dan mendorong terwujudnya masyarakat yang cerdas dengan memiliki pendidikan yang cukup sehingga memiliki daya saing. Kedua berkomitmen menangani masalah pendidikan di Kota Bogor dengan cara memberikan beasiswa kepada para pelajar, santri dan mahasiswa. Dan terakhir untuk memberikan tunjangan guru ngaji yang telah membantu anak-anak generasi bangsa ini agar tumbuh menjadi anak-anak yang cerdas, berakhak mulia dan bertakwa kepada Allah SWT (Laporan BAZNAS Kota Bogor, 2014: 20).

Sebaran wilayah program Bogor Cerdas meliputi Kota Bogor yang terdiri dari 6 kecamatan, yaitu Kecamatan Bogor Timur, Bogor Barat, Bogor Selatan, Bogor Utara, Bogor Tengah dan Tanah Sareal (Laporan BAZNAS Kota Bogor, 2014: 21). Bentuk kegiatan dari kegiatan Bogor Cerdas antara lain; program layanan beasiswa reguler yang diselenggarakan oleh Baznas Kota Bogor merupakan wujud komitmen Baznas Kota Bogor dalam menangani masalah pendidikan dikota Bogor, beasiswa yang diberikan bersifat rutin dan dibagikan dalam setiap bulannya.

Pada program ini yang menerima bantuan beasiswa adalah para pelajar, santri dan mahasiswa, dimana para penerima manfaat ini mendapatkan bantuan biaya pendidikan secara rutin dari Baznas Kota Bogor. Para penerima manfaat program ini diprioritaskan untuk masyarakat miskin yang ada di kota Bogor dan untuk memastikannya semua calon penerima manfaat akan dilakukan verifikasi lapangan baik ke rumah calon penerima manfaat maupun ke sekolah tempat penerima manfaat mengenyam pendidikannya.

Program lainnya adalah layanan beasiswa kasusistik (non reguler), program layanan ini untuk merespon permohonan masyarakat yang datang ke BAZNAS Kota Bogor untuk meminta bantuan dalam masalah biaya pendidikan, karena jumlah kuota penerima beasiswa reguler sudah diplot dan ditentukan pada saat rapat kerja awal tahun, sehingga untuk mengakomodir masyarakat yang tidak masuk program beasiswa reguler Baznas Kota Bogor menyiapkannya dengan program beasiswa 
kausistik. Program beasiswa kausistik ini dilakukan karena masyarakat yang datang dan meminta bantuan biaya pendidikan dari BAZNAS cukup banyak. Namun semua permohonan akan dilakukan verifikasi terlebih dahulu guna memastikan bantuan dapat tersalurkan dengan baik dan sesuai dengan sasaran.

Layanan guru ngajiku, program tunjangan guru ngaji merupakan upaya BAZNAS Kota Bogor dalam upaya memberikan penghargaan kepada para guru ngaji yang telah membantu anak-anak generasi bangsa ini agar tumbuh menjadi anak-anak yang cerdas, berakhlak mulia dan bertakwa kepada Allah SWT. Oleh sebab itu sudah sepantasnya para mujahid ini diberikan penghargaan dan perhatian yang besar oleh kita semua terutama para pemangku kebijakan karena kiprahnya yang sangat mulia ini. Tunjangan yang diberikan kepada para guru ngaji ini dianggarkan setiap bulan dan diberikannya pada setiap semester sekali tepatnya pada bulan Juni dan bulan Desember, besaran per bulannya adalah sebesar Rp 100,000 jadi karena diberikannya per semester totalnya menjadi sebesar Rp 600,000 sehingga dalam satu tahun per guru ngaji mendapat tunjangan sebesar Rp 1,200,000.

Pada tahun 2014 ini jumlah guru ngaji yang mendapatkan tunjangan dari BAZNAS Kota Bogor sebanyak 150 guru ngaji, Pada tahun 2014 jumlahnya dapat meningkat dari tahun 2013 yang hanya sebanyak 100 guru ngaji. BAZNAS Kota Bogor berharap setiap tahun ada peningkatan baik dari jumlah guru ngaji yang mendapat tunjangan maupun jumlah nominal tunjangan yang diberikan. Harapan ini dapat diwujudkan jika kesadaran masyarakat dalam mengeluarkan zakat, infak dan shadaqah makin meningkat (Laporan BAZNAS Kota Bogor, 2014: 20-23).

\section{Gambaran Responden}

Dalam penelitian ini data responden yang diambil adalah para karyawan BAZNAS Kota Bogor. Sampel yang dijadikan dalam penelitian ini adalah bagian dari populasi yang dijadikan subyek. Teknik sampling yang digunakan adalah teknik convenience sampling. Convenience sampling adalah istilah umum yang mencakup variasi luasnya prosedur pemilihan responden. Convenience sampling berarti unit sampelnya yang ditarik mudah dihubungi, tidak menyusahkan, mudah untuk mengukur dan bersifat kooperatif (Hamid, 2007: 30).

Dalam penelitian ini sampel yang diteliti sejumlah 30 responden, dengan melakukan penyebaran kuisioner secara langsung kepada responden yang berada di BAZNAS Kota Bogor dan dijadikan sebagai sampel penelitian kemudian mengajukan pertanyaan tertutup dan terbuka. Adapun karakteristik responden adalah sebagai berikut:

\section{Jenis Kelamin Responden}

Berdasarkan hasil penelitian yang diperoleh dari 30 responden yang terdapat pada BAZNAS Kota Bogor, secara lebih rinci karakteristik responden berdasarkan jenis kelamin dapat dilihat pada tabel 2:

Tabel 2.

Jenis Kelamin Responden

\begin{tabular}{|l|l|l|l|}
\hline No & Jenis Kelamin & $\begin{array}{l}\text { Jumlah } \\
\text { Responden }\end{array}$ & Presentase \\
\hline 1 & Laki-laki & 21 & $70 \%$ \\
\hline 2 & Perempuan & 9 & $30 \%$ \\
\hline \multicolumn{2}{|c|}{ Jumlah } & 30 & $100 \%$ \\
\hline
\end{tabular}

Berdasarkan data kuisioner yang diberikan kepada responden terdapat 21 responden laki-laki dan 9 responden perempuan. Hal ini menunjukkan bahwa 
jumlah laki-laki mendominasi karyawan di BAZNAS kota Bogor atau dengan kata lain sebagian besar karyawan di BAZNAS kota Bogor (70 persen) adalah laki-laki. Hal ini disebabkan karena rincian pekerjaan untuk di BAZNAS cenderung membutuhkan mobilitas yang tinggi dan flexibilitas untuk bepergian kebeberapa tempat.

\section{Tingkat Pendidikan Responden}

Berdasarkan hasil penelitian yang diperoleh dari 30 responden yang terdapat pada BAZNAS Kota Bogor, secara lebih rinci karakteristik responden berdasarkan pendidikan responden dapat dilihat pada tabel 3.

Tabel 3.

Tingkat Pendidikan Responden

\begin{tabular}{|l|l|l|l|}
\hline No & Pendidikan & $\begin{array}{c}\text { Jumlah } \\
\text { Responden }\end{array}$ & Presentase \\
\hline 1 & SD & - & - \\
\hline 2 & SMP & - & - \\
\hline 3 & SMA & 11 & $37 \%$ \\
\hline 4 & D3 & - & - \\
\hline 5 & S1 & 15 & $50 \%$ \\
\hline 6 & S2 & 4 & $13 \%$ \\
\hline Jumlah & 30 & $100 \%$ \\
\hline
\end{tabular}

Berdasarkan data kuisioner yang diberikan kepada responden diketahui bahwa tingkat pendidikan dari 30 responden, terdapat sebanyak 11 orang responden (37\%) dengan tingkat pendidikan SMA, 15 orang responden (50\%) dengan tingkat pendidikan S1, dan 4 orang responden (13\%) dengan tingkat pendidikan S2. Dari data tersebut penulis dapat memberikan gambaran bahwa, tingkat pendidikan paling tinggi dari seluruh responden adalah tingkat pendidikan S1.

\section{Usia Responden}

Berdasarkan hasil penelitian yang diperoleh dari 30 responden yang terdapat pada BAZNAS Kota Bogor, secara lebih rinci karakteristik responden berdasarkan usia responden dapat dilihat pada tabel 4:

Tabel 4.

Usia Responden

\begin{tabular}{|l|l|l|l|}
\hline No & Usia & $\begin{array}{l}\text { Jumlah } \\
\text { Responden }\end{array}$ & Presentase \\
\hline 1 & $<25$ & 6 & $20 \%$ \\
\hline 2 & $25-35$ & 12 & $40 \%$ \\
\hline 3 & $35-45$ & 8 & $26 \%$ \\
\hline 4 & $45-55$ & 2 & $7 \%$ \\
\hline 5 & $55>$ & 2 & $7 \%$ \\
\hline Jumlah & 30 & $100 \%$ \\
\hline
\end{tabular}

Berdasarkan data kuisioner yang diberikan kepada responden, terdapat 6 orang (20\%) responden dengan rentan usia dibawah 25 tahun, 12 orang (40\%) responden dengan rentan usia 25 - 35 tahun, 8 orang $(26 \%)$ responden dengan rentan usia 35 - 45 tahun, 2 orang (7\%) responden dengan rentan usia 45 - 55 tahun, dan 2 orang (7\%) responden dengan rentan usia di atas 55 tahun.

\section{Rencana, Proses, dan Evaluasi Pendistribusian Dana Zakat Program Bogor Cerdas}

Menurut ketua penanggung jawab program Bogor Cerdas, ada beberapa rencana yang dilakukan oleh BAZNAS Kota Bogor untuk pendistribusikan dana zakatnya pada program Bogor Cerdas, yaitu:

1. Menentukan karakteristik mustahik penerima program Bogor Cerdas dengan cara mendistribusikan dana zakatnya kepada mustahik yang tergolong pada asnaf fakir, miskin, dan fisabilillah yang masih berstatus pelajar, santri, ataupun mahasiswa.

2. Melakukan survey dengan cara mendatangi rumah calon penerima bantuan program Bogor Cerdas demi mengetahui kondisi keluarga baik dari segi materi (pendapatan orang tua) 
maupun non materi (keadaan/kondisi rumah) mustahik tersebut.

3. Menentukan calon penerima program Bogor Cerdas dari hasil survey yang telah dilakukan, sehingga BAZNAS Kota Bogor dapat mengetahui mustahik tersebut tergolong ke dalam asnaf yang mana.

4. Melakukan pengkroscekan ulang dari data survey, form dan berkas pengajuan program Bogor Cerdas untuk mengetahui layak atau tidaknya mustahik tersebut menerima bantuan program Bogor Cerdas ini.

5. Melibatkan tujuan program Bogor Cerdas untuk menentukan mustahik penerima bantuan program Bogor Cerdas dimana tujuan program ini adalah membantu mustahik agar bisa mengenyam pendidikan sehingga bisa menjadi insan yang cerdas.

6. Pengkarakteristikan cerdas, yaitu dimana mustahik tersebut dapat bersekolah dan mendapatkan pendidikan yang layak sehingga adanya ilmu dan kapasitas yang bertambah pada diri mustahik tersebut.

7. Menentukan besaran dana yang akan didistribusikan dengan cara melihat anggaran yang dana yang dianggarkan untuk program Bogor Cerdas, mengkategorian golongan atau penentuan great mustahik dari hasil survey yang dilakukan. Untuk program beasiswa akuistik, besaran dana yang disalurkan tergantung pada surat tunggakan yang dikeluarkan dari pihak sekolah tempat mustahik tersebut belajar.

8. Memberikan keputusan layak atau tidaknya dan mustahik tersebut menerima bantuan program Bogor Cerdas beserta dengan keputusan penentuan besaran dana yang akan diterima, dimana keputusan ini diputuskan oleh ketua bidang pendayagunaan atas rekomendasi surveyor dengan persetujuan dari ketua BAZNAS Kota Bogor.

9. Penentuan alur pengajuan program dengan cara mustahik mengisi form pengajuan program dan melampirkan berkas pengajuan yang lengkap (KTP, KK, SK pelajar/mahasiswa, SKTM), melampirkan tunggakan/tagihan dari sekolah (untuk program beasiswa kasuistik). Untuk program Guru Ngajiku, wajib melampirkan surat keterangan mengajar mengaji dan data murid dari lembaga tempatnya mengajar ngaji.

10. Berkonsultasi kepada pihak sekolah guna mengetahui informasi mustahik tentang menerima atau tidak bantuan dari pemerintah (BOS). Informasi ini bertujuan untuk meminimalisir risiko agar mustahik tersebut tidak menerima bantuan dari dua pihak atau lebih.

11. Melakukan pendistribusian dana zakat pertiga bulan satu kali untuk program beasiswa regular dengan mengumpulkan para mustahik penerima dana zakat Program Bogor Cerdas dan wajib memberikan laporan pembayaran berupa kuitansi pembayaran. Untuk beasiswa kasuistik yang bersifat insidental, pihak BAZNAS langsung yang membayarkan ke sekolah tempat mustahik tersebut belajar, dan untuk Program Guru Ngajiku pendistribusian dilakukan enam bulan sekali dengan mengumpulkan para guru ngaji di suatu tempat atau langsung dating ke BAZNAS Kota Bogor 
12. Melakukan pendataan kembali data base mustahik.

13. Melakukan rapat evaluasi setiap satu semester sekali-kali dan juga setiap satu periode sekali.

\section{Program Bogor Cerdas}

Program Bogor Cerdas merupakan layanan yang diselenggarakan oleh Baznas Kota Bogor dalam menangani masalah pendidikan dan penguatan kapasitas masyarakat Kota Bogor. Program ini diharapkan dapat membantu dan mendorong terwujudnya masyarakat yang cerdas dengan memiliki pendidikan yang cukup sehingga memiliki daya saing. Kebutuhan akan pendidikan yang baik merupakan hak semua warga dimana Negara seharusnya menjamin warganya untuk mendapatkan akses pendidikan yang memadai sehingga tidak ada lagi masyarakat yang kesulitan mendapatkan pendidikan yang layak.

Di Kota Bogor pemerintah Kota telah menunjukkan komitmennya dalam menjamin warganya agar dapat sekolah dengan membuat kebijakan menggratiskan biaya sekolah sampai tingkatan sekolah menengah pertama (SMP) disekolahsekolah negeri yang ada di Kota Bogor, tentu kebijakan ini sangat strategis bagi kepentingan bangsa kedepan. Belum lama ini Walikota Bogor juga telah mengeluarkan kebijakan yang strategis terkait dengan upaya mendorong dan membantu masyarakat untuk mendapatkan pendidikan yang cukup dengan menghapus biaya masuk sekolah tingkatan sekolah menengah atas di seluruh sekolah-sekolah SMA negeri yang ada di kota Bogor.

$$
\text { Adapun kegiatan yang }
$$

diselenggarakan oleh Baznas Kota Bogor pada program pendidikan dibagi menjadi empat bagian, yaitu: pertama, bantuan reguler setiap bulan untuk pelajar, santri dan mahasiswa. Kedua, tunjangan reguler untuk guru ngaji, ketiga bantuan pendidikan bersifat kasuistis (non reguler) dan keempat, mengadakan pelatihan peningkatan kapasitas bagi masyarakat.

\section{Layanan Beasiswa Reguler}

Program layanan beasiswa reguler yang diselenggarakan oleh Baznas Kota Bogor merupakan wujud komitmen Baznas Kota Bogor dalam menangani masalah pendidikan di kota Bogor, beasiswa yang diberikan bersifat rutin dan dibagikan dalam setiap bulannya. Pada program ini yang menerima bantuan beasiswa adalah para pelajar, santri dan mahasiswa, dimana para penerima manfaat ini mendapatkan bantuan biaya pendidikan secara rutin dari Baznas Kota Bogor. Para penerima manfaat program ini diprioritaskan untuk masyarakat miskin yang ada dikota Bogor dan untuk memastikannya semua calon penerima manfaat akan dilakukan verifikasi lapangan baik ke rumah calon penerima manfaat maupun ke sekolah tempat penerima manfaat mengenyam pendidikannya.

Tentu hal ini dilakukan dalam upaya memastikan agar program layanan ini berjalan secara baik dan tepat sasaran kepada para mustahik yang berhak menerimanya. Sehingga pendistribusian dana zakat yang ada pada program ini pun dapat terealisaikan dengan seefektif mungkin. Adapun jumlah penerima manfaat berdasarkan tempat tinggal dan peruntukannya adalah sebagai berikut: 
Tabel 5.

Jumlah Penerima Manfaat Berdasarkan Peruntukkannya

\begin{tabular}{|c|c|c|c|c|c|}
\hline No & $\begin{array}{l}\text { Alamat } \\
\text { Tinggal }\end{array}$ & $\begin{array}{l}\text { Beasiswa } \\
\text { Pelajar }\end{array}$ & $\begin{array}{l}\text { Bea } \\
\text { Santri }\end{array}$ & $\begin{array}{l}\text { Bea } \\
\text { Sarjana }\end{array}$ & Jumlah \\
\hline 1 & $\begin{array}{l}\text { Bogor } \\
\text { Barat }\end{array}$ & 1 & 4 & & 5 \\
\hline 2 & $\begin{array}{l}\text { Bogor } \\
\text { Selatan }\end{array}$ & 9 & 7 & 2 & 18 \\
\hline 3 & $\begin{array}{l}\text { Bogor } \\
\text { Tengah }\end{array}$ & 4 & 6 & 2 & 12 \\
\hline 4 & $\begin{array}{l}\text { Bogor } \\
\text { Timur }\end{array}$ & 7 & - & - & 7 \\
\hline 5 & $\begin{array}{l}\text { Bogor } \\
\text { Utara }\end{array}$ & 9 & 6 & 3 & 18 \\
\hline 6 & $\begin{array}{l}\text { Tanah } \\
\text { Sareal }\end{array}$ & 5 & 7 & - & 12 \\
\hline \multicolumn{2}{|c|}{$\begin{array}{c}\text { Total } \\
\text { Penerima } \\
\text { Manfaat }\end{array}$} & 35 & 30 & 7 & 72 \\
\hline
\end{tabular}

Pada tabel 5 dapat diketahui jumlah keseluruhan penerima manfaat program beasiswa reguler Baznas Kota Bogor berdasarkan peruntukkannya, sedangkan untuk besaran bantuan yang diberikan adalah seperti terdapat pada tabel berikut ini:

Tabel 6

Besaran Bantuan Berdasarkan Peruntukan

\begin{tabular}{|c|c|c|}
\hline No & Program & $\begin{array}{c}\text { Besaran } \\
\text { Bantuan } \\
\text { (Rp) }\end{array}$ \\
\hline 1 & Beasiswa Untuk & $\begin{array}{c}250,000- \\
300,000\end{array}$ \\
\hline 2 & Pelajar & 300,000 \\
\hline 3 & BeaSantri untuk & Santri \\
\hline
\end{tabular}

Sumber: Laporan BAZNAS Kota Bogor, 2014.

\section{Layanan Beasiswa Kasuistik (Non Reguler)}

Program layanan ini untuk merespon permohonan masyarakat yang datang ke Baznas Kota Bogor untuk meminta bantuan dalam masalah biaya pendidikan, karena jumlah kuota penerima beasiswa reguler sudah diplot dan ditentukan pada saat rapat kerja awal tahun, sehingga untuk mengakomodir masyarakat yang tidak masuk program beasiswa reguler Baznas Kota Bogor menyiapkannya dengan program beasiswa kausistik. Program beasiswa kausistik ini dilakukan karena masyarakat yang datang dan meminta bantuan biaya pendidikan dari Baznas cukup banyak. Namun semua permohonan akan dilakukan verifikasi terlebih dahulu guna memastikan bantuan dapat tersalurkan dengan baik dan sesuai dengan sasaran.

Pada program layanan bantuan kasuistik ini paling banyak permintaan pada saat menjelang akhir semester, permohonan biasanya masalah tunggakan biaya pendidikan perbulan. Karena biasanya menjelang ujian semesteran pihak sekolah sering melakukan ultimatum kepada siswa agar segala tunggakan harus dilunasi sebelum ujian dilaksanakan, sehingga banyak permohonan yang datang ke Baznas untuk meminta bantuan biaya pendidikan. Oleh karena itu Baznas dalam upaya mengatasi persoalan-persoalan klasik ini telah membangun komuniasi secara produktif dan membuat kerjasama dengan stakeholders terkait di bidang pendidikan guna meminimalisir siswa yang terpaksa tidak mengikuti ujian semesteran dikarenakan tidak mampu membayar tunggakan biaya pendidikan.

Kedepan tentu harus dicarikan solusi yang permanen dalam mengatasi masalah yang berkaitan dengan siswasiswa yang orangtuanya memiliki keterbatasan ekonomi. Seperti yang telah dibahas sebelumnya bahwa proses pencairan bantuan yang diberikan Baznas 
terhadap penerima manfaat bergantung pada perkembangan asupan anggaran para muzaki yang membayarkan zakat, infak dan shadaqahnya ke Baznas Kota Bogor, sehingga hal tersebut sedikit mengganggu dari kelancaran pendistribusiannya karena besaran alokasi anggaran yang ditetapkan oleh bagian keuangan itu hanya bersifat asumsi.

\section{Layanan Tunjangan Guru Ngajiku}

Program tunjangan guru ngaji merupakan upaya Baznas Kota Bogor dalam upaya memberikan penghargaan kepada para guru ngaji yang telah membantu anak-anak generasi bangsa ini agar tumbuh menjadi anak-anak yang cerdas, berakhlak mulia dan bertakwa kepada Allah SWT. Oleh sebab itu sudah sepantasnya para mujahid ini diberikan penghargaan dan perhatian yang besar oleh kita semua terutama para pemangku kebijakan karena kiprahnya yang sangat mulia ini. Tunjangan yang diberikan kepada para guru ngaji ini dianggarkan setiap bulan dan diberikannya pada setiap semester sekali tepatnya pada bulan juni dan bulan desember, besaran per bulannya adalah sebesar Rp 100,000 jadi karena diberikannya per semester totalnya menjadi sebesar Rp 600,000 sehingga dalam satu tahun per guru ngaji mendapat tunjangan sebesar Rp 1,200,000.

Pada tahun 2014 ini jumlah guru ngaji yang mendapatkan tunjangan dari Baznas Kota Bogor sebanyak 150 guru ngaji, alhamdulilah pada tahun 2014 ini jumlahnya dapat meningkat dari tahun sebelumnya 2013 sebanyak 100 guru ngaji. Mudah-mudahan Baznas Kota Bogor berharap setiap tahun ada peningkatan baik dari jumlah guru ngaji yang mendapat tunjangan maupun jumlah nominal tunjangan yang diberikan. Tentu saja harapan ini dapat terwujud jika kesadaran masyarakat dalam mengeluarkan zakat, infak dan shadaqah makin meningkat. Di bawah ini dapat dilihat data sebaran guru ngaji yang mendapat tunjangan dari Baznas Kota Bogor.

Tabel 8

Jumlah dan Data Sebaran Guru Ngaji Tahun 2014

\begin{tabular}{|l|l|l|}
\hline No & \multicolumn{1}{|c|}{ Wilayah } & \multicolumn{1}{|c|}{$\begin{array}{c}\text { Jumlah Guru } \\
\text { Ngaji }\end{array}$} \\
\hline 1 & $\begin{array}{l}\text { Kecamatan Bogor } \\
\text { Barat }\end{array}$ & 34 Mustahik \\
\hline 2 & $\begin{array}{l}\text { Kecamatan Bogor } \\
\text { Selatan }\end{array}$ & 42 Mustahik \\
\hline 3 & $\begin{array}{l}\text { Kecamatan Bogor } \\
\text { Timur }\end{array}$ & 8 Mustahik \\
\hline 4 & $\begin{array}{l}\text { Kecamatan Bogor } \\
\text { Tengah }\end{array}$ & 22 Mustahik \\
\hline 5 & $\begin{array}{l}\text { Kecamatan Bogor } \\
\text { Utara }\end{array}$ & 18 Mustahik \\
\hline 6 & $\begin{array}{l}\text { Kecamatan Tanah } \\
\text { Sareal }\end{array}$ & 26 Mustahik \\
\hline & \multicolumn{1}{|c|}{ Total } & 150 Mustahik \\
\hline
\end{tabular}

Sumber: Laporan BAZNAS Kota Bogor, 2014.

\section{Uji Validitas dan Reliabilitas}

Uji realiabilitas dari masing-masing faktor menggunakan Cronbach's Alpha. Kuesioner dinyatakan reliabel jika mempunyai nilai koefisien alpha yang lebih besar > 0,6. Nilai Cronbach's Alpa sebesar 0,941 diatas 0,6 maka instrumen dinyatakan reliabel. Dari hasil pengujian instrumen maka semua instrumen dikatakan reliabel karena nilai koefisien Cronbach Alpha yang diperoleh lebih besar dari 0,6 (>0,6). Uji validitas dilakukan untuk menguji kuesioner layak untuk digunakan sebagai instrumen penelitian. Valid berarti instrumen tersebut dapat digunakan untuk mengukur apa yang seharusnya diukur. Validitas dalam penelitian ini menggunakan bantuan Software SPSS versi 20 for Windows untuk memperoleh hasil yang terarah. 
Kriteria dari validitas yaitu bila koefisien kolerasi masing-masing pertanyaan dengan nilai Corrected Item Total Correlation lebih besar atau sama dengan $r$ tabel. Hasil uji validitas melalui program SPSS 20 memberikan hasil bahwa koefisien kolerasi dari 13 butir pertanyaan, dikatakan 13 yang valid dengan skor total > 0,361 dan dapat diolah lebih lanjut.

\section{Importance Performance Analysis (IPA)}

Dalam pengumpulan data, penulis menggunakan instrumen wawancara dan angket. Masing-masing instrumen tersebut berguna untuk melengkapi data yang diperoleh peneliti.Setelah mengkategorikan hasil angket, perhitungan yang peneliti gunakan adalah untuk mengetahui besar kecilnya efektifitas program pendistribusian dana zakat di BAZNAS Kota Bogor, maka teknik analisa data yang digunakan dalam penelitian ini adalah dengan menggunakan Importance Performance Analysis (IPA). Metode ini digunakan untuk menganalisis tingkat kepentingan dan kenyataan. Responden memberikan penilaian terhadap indikator program pendistribusian dana zakat sesuai dengan skor yang diberikan.

\section{Analisis Importance Performance} Analysis (IPA) juga dapat memberikan hasil kesenjangan dari setiap atribut, kesenjangan tersebut diperoleh dari skor kenyataan kinerja dari setiap atribut. Kesenjangan atribut ini diperoleh dari skor kenyataan (ei) yang dilakukan dan kepentingan (bi) yang didapatkan. Rumus yang digunakan untuk mendapatkan kesenjangan (GAP) adalah: "Gap adalah Rata-rata kenyataan dikurangi Rata-rata kepentingan". Jika nilai ei-bi $=0$, maka dapat diartikan bahwa indikator program pendistribusian dana zakat saat ini diasumsikan telah efektif. Jika nilai (ei-bi) positif atau ei $\geq$ bi, maka dapat diasumsikan bahwa indikator lebih baik dibandingkan dengan yang diharapkan BAZNAS Kota Bogor, sebaliknya jika nilai (ei-bi) negatif atau ei $\leq$ bi, maka dapat diasumsikan belum memenuhi indikator kepentingan BAZNAS Kota Bogor.

Berdasarkan hasil perhitungan yang diolah, terlihat bahwasannya variabelvariabel yang ada saat ini belum sepenuhnya sesuai dengan harapan karena rata-rata dari hasil gap diatas menunjukkan kurang dari angka nol kecuali variabel pada nomor dua. Dengan demikian, maka pihak BAZNAS Kota Bogor dapat mengetahui bahwa nilai kenyataan dari kepentingan masih banyak terdapat kekurangan yang bisa menjadi masukan untuk perbaikan kedepannya.

Setelah menghitung tingkat analisis gap dari variabel yang ada, maka selanjutnya adalah melakukan analisis Importance Performance Analysis (IPA). Analisis IPA dimulai dengan menghitung rata-rata tingkat realitas atau kenyataan (X) dan tingkat harapan atau kepentingan (Y). Setelah menghitung tingkat rata-rata $\mathrm{X}$ dan $Y$, selanjutnya ratakan kembali nilai $X$ dan $Y$, dimana nilai rata-rata tersebutakan menjadi pembatas dalam diagram IPA.

Adapun hasil rata-rata tingkat performance $(\mathrm{X})$ menunjukkan bahwa ratarata nilai kenyataan adalah 3,78. Nilai tersebut akan digunakan sebagai batas kuadran dalam analisis IPA pada sumbu X. Untuk itu, setelah mengetahui hasil perhitungan perhitungan rata-rata performance, maka selanjutnya akan mencari rata-rata tingkat kepentingan (importance), maka perhitungan rata-rata tingkat kepentingan menunjukkan bahwa nilai rata-rata dari tingkat kepentingan adalah 4,10. Nilai tersebut akan digunakan sebagai batas kuadran IPA pada sumbu Y. Nilai-nilai tersebut akan dimasukkan 
kedalam diagram Importance Performance Analysis (IPA) pada gambar 2:

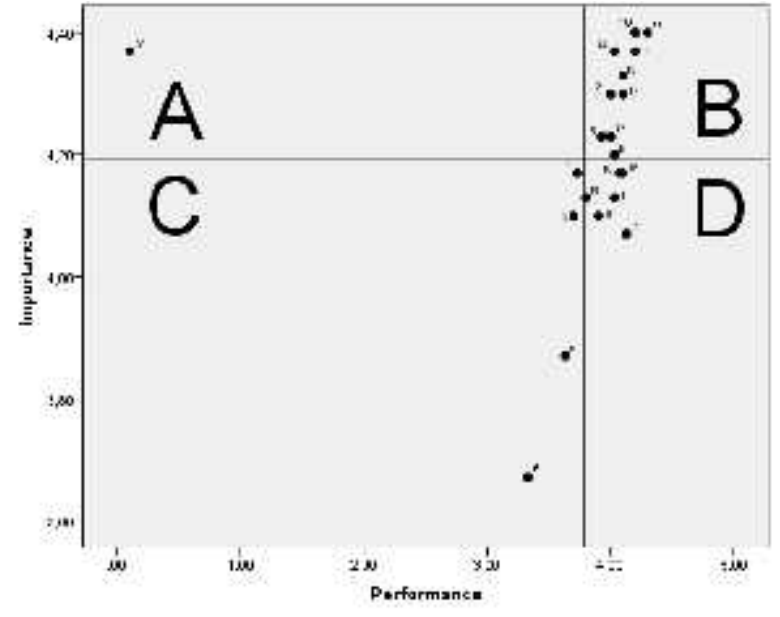

Gambar 2. Diagram Kartesius Importance Performance Analysis BAZNAS Kota Bogor

Pada gambar 2. diagram kartesius menunjukkan bahwa efektifitas program pendistribusian dana zakat BAZNAS Kota Bogor dibagi menjadi 4 kuadran diantaranya yaitu:

Kuadran A

Pada kuadran ini (A) menunjukkan faktor atau atribut yang dianggap mempengaruhi efektifitas program pendistribusian dana zakat, namun pada kenyataannya faktor pada kuadran ini belum diimplementasikan dengan baik, sehingga faktor-faktor dalam kuadran ini perlu ditingkatkan kembali, yang termasuk dalam kuadran ini adalah record, dokumentasi dan notulensi hasil rapat (20). Kuadran B

Pada kuadran ini (B) "High Importance High Performance" dianggap sebagai faktor yang penting atau diharapkan oleh BAZNAS Kota Bogor dan pada kenyataannya faktor-faktor ini telah diimplementasikan pada program pendistribusian dana zakat, maka dari itu, faktor-faktor yang berada pada kuadran ini wajib dipertahankan. Dan yang termasuk dalam kuadran ini adalah pertimbangan penerima program (5), penentuan mustahik berdasarkan tujuan program (7), kelengkapan administrasi mustahik (9), program Bogor Cerdas hanya untuk masyarakat dhuafa (12), program Bogor Sehat hanya untuk masyarakat dhuafa (13), program dakwah dan kemanusiaan hanya untuk masyarakat dhuafa (14), manajemen risiko terhadap program (17), rapat evaluasi program (19), penerima program Bogor Cerdas harus berpretasi (11), dan peninjauan ulang program (21).

Kuadran C

Pada kuadran ini (C) memiliki tingkat yang rendah dan dianggap tidak penting oleh BAZNAS Kota Bogor, dan tingkat implementasi pada faktor-faktor ini biasa-biasa saja, sehingga BAZNAS Kota Bogor tidak perlu memprioritaskan faktorfaktor tersebut. Pada kuadran ini, faktorfaktor tersebut adalah wawancara terhadap msutahik (3), tes/ujian penerima program (4), pengecekan ulang data mustahik penerima program (6), dan laporan progres mustahik (15).

Kuadran D

Pada kuadran ini (D) dianggap sebagai faktor-faktor yang kurang penting atau kurang diharapkan oleh BAZNAS Kota Bogor, akan tetapi implementasi yang dirasakan dari faktor-faktor pada kuadran ini sangatlah berlebihan, maka dari itu BAZNAS Kota Bogor harus mengalokasikan sumberdayanya kepada faktor-faktor lain yang mempunyai prioritas lebih tinggi untuk peningkatan. Adapun yang termasuk dalam kuadran ini adalah prosedur pengajuan program (1), melakukan observasi sebelum penyaluran dana zakat (2), data base mustahik (8), pertimbangan usia mustahik (10), melakukan peninjauan progres mustahik (16), dan harapan lembaga terhadap mustahik (18). 
Analisis

Efektifitas

Program

Pendistribusian Dana Zakat di BAZNAS

Kota Bogor dengan Customer

Statification Index (CSI)

Metode analisis CSI ini bertujuan untuk mengukur dan mengetahui tingkat efektivitas program pendistribusian dana zakat di BAZNAS kota Bogor. Metode analisis CSI ini merupakan suatu indeks yang berfungsi untuk mengukur tingkat efektifitas program pendistribusian dana zakat yang telah dilakukan oleh BAZNAS kota Bogor.

Metode analisis CSI ini dimulai dengan menentukan Mean Importance Score (MIS) dan Mean Statisfaction Score (MSS). Cara menentukan metode analisis CSI adalah sebagai berikut; MIS, didapatkan dari rata-rata, dari tingkat harapan dibagi dengan jumlah responden. MSS, didapatkan dari rata-rata, dari tingkat kenyataan atau kinerja dibagi dengan jumlah responden. WF (Weight Faktors), didapatkan dengan cara menghitung nilai MIS perfaktor dibagi dengan total MIS seluruh atribut. WS (Weight Score), didapatkan dari mengalikan WF dengan MSS.CSI, didapatkan dari menjumlahkan seluruh faktor WS atau disebut dengan WT dan membaginya dengan skala nominal 5 dikalikan 100\%.

Berdasarkan data hasil perhitungan

Customer Satisfaction Index (CSI), responden efektifitas program pemberdayaan dana zakat di BAZNAS kota Bogor, dapat disimpulkan bahwa hasil data pengelolaan data dengan metode analisis CSI ini adalah 75,63\%. Menurut Cahya (2014: 118) berdasarkan tabel kriteria nilai CSI, nilai 75,63 berada diantara 70,01 90,00 , nilai tersebut menunjukkan bahwa pendapat responden efektifitas pendistribusian dana zakat di BAZNAS kota Bogor berpendapat rata-rata sangat puas dengan kualitas program pendistribusian dana zakat yang dilakukan oleh BAZNAS kota Bogor, maka dari itu BAZNAS kota Bogor harus tetap mempertahankan kualitas program pendistribusian dana zakat yang telah diterapkan oleh responden dan berusaha untuk meningkatkan kinerja responde terutama dalam mendistribusikan dana zakat, sehingga diharapkan dapat meningkatkan kualitas pihak BAZNAS kota Bogor untuk mendistribusikan dana zakatnya.

\section{KESIMPULAN DAN IMPLIKASI}

Berdasarkan hasil penelitian dan pembahasan dapat disimpulkan beberapa hal, sebagai berikut:

1. Program pendistribusian dana zakat yanag ada pada lembaga BAZNAS Kota Bogor yaitu Bogor sehat, Bogor cerdas, dakwah dan kemanusiaan, Bogor berdaya. Diantara program-program tersebut, Program Bogor Cerdas memiliki eksistensi lebih besar diantara program yang lain.

2. Penilaian responden mengenai efektifitas program pendistribusian dana zakat terdiri dari tahapan pendistribusian, dokumentasi, karakteristik mustahik, pengawasan dan evaluasi. Hasil dari penilaian responden telah digambarkan pada diagram Importance Performance Analysis (IPA), dan dari diagram tersebut menunjukkan bahwa faktor atau atribut yang dianggap mempengaruhi efektifitas program pendistribusian dana zakat, namun pada kenyataannya faktor ini belum diimplementasikan dengan baik, sehingga faktor ini perlu ditingkatkan kembali, dan faktor tersebut adalah record, dokumentasi dan notulensi hasil rapat."High Importance High 
Performance" dianggap sebagai faktor yang penting atau diharapkan oleh BAZNAS Kota Bogor dan pada kenyataannya faktor-faktor ini telah diimplementasikan pada program pendistribusian dana zakat, maka dari itu, faktor-faktor ini wajib dipertahankan. Faktor tersebut adalah pertimbangan penerima program, penentuan mustahik berdasarkan tujuan program, kelengkapan administrasi mustahik, program Bogor cerdas hanya untuk masyarakat dhuafa, program Bogor sehat hanya untuk masyarakat dhuafa, Program dakwah dan kemanusiaan hanya untuk masyarakat dhuafa, manajemen risiko terhadap program, Rapat evaluasi program, penerima program Bogor Cerdas harus berpretasi, dan peninjauan ulang program. Adapun faktor yang memiliki tingkat yang rendah dan dianggap tidak penting oleh BAZNAS Kota Bogor, dan tingkat implementasi pada faktor-faktor ini biasa-biasa saja, sehingga BAZNAS Kota Bogor tidak perlu memprioritaskan faktor-faktor tersebut. Dan faktor-faktor tersebut adalah wawancara terhadap mustahik, tes atau ujian penerima program, pengecekan ulang data mustahik penerima program, dan laporan progres mustahik. Selain itu, faktor yang dianggap sebagai faktor-faktor yang kurang penting atau kurang diharapkan oleh BAZNAS Kota Bogor, akan tetapi implementasi yang dirasakan dari faktor-faktor ini sangatlah berlebihan. adapun yang termasuk faktor tersebut adalah prosedur pengajuan program, Melakukan observasi sebelum penyaluran dana zakat, data base mustahik, pertimbangan usia mustahik, melakukan peninjauan progress mustahik, dan harapan lembaga terhadap mustahik.

Berdasarkan hasil perhitungan dengan metode analisis Customer Satisfaction Index (CSI) dari hasil jawaban yang diberikan responden terhadap efektifitas program pendistribusian dana zakat di BAZNAS kota Bogor, dapat disimpulkan bahwa nilai CSI dari penelitian ini adalah $75,63 \%$. Berdasarkan tabel kriteria nilai CSI, nilai 75,63 berada diantara 70,01-90,00, nilai tersebut menunjukkan bahwa pendapat responden efektifitas pendistribusian dana zakat di BAZNAS kota Bogor berpendapat rata-rata sangat puas (sudah efektif) dengan kualitas program pendistribusian dana zakat yang dilakukan oleh BAZNAS kota Bogor.

\section{DAFTAR PUSTAKA}

Ali, Muhammad Daud. 2006, Sistem Ekonomi Islam Zakat Dan Wakaf, Jakarta: UI Press.

Al-Muhsin, Fakhruddin. 2011, Ensiklopedia Mini Zakat, Jakarta: Daarul Ilmi Publishing.

BAZ Kota Bogor. 2010, Ragam Cerita \& Karya BAZ Kota Bogor.

Cahya, Nur. 2014, Efektifitas Sosialisasi Asuransi Syariah PT. PRU Syariah Bogor (Studi pada Pasar di Bogor), Skripsi, Bogor: Universitas Djuanda Bogor.

Hafidhuddin, Didin. 2000, Zakat Dalam Perekonomian Modern, Jakarta: Gema Insani.

Hamid, Syamsul Rijal. 2011, Petuah petuah Rasulullah 5: Zakat, Jakarta: Abdi Tandur.

Idris, Safwan. 1997, Gerakan Zakat dalam Pemberdayaan Ekonomi Ummat, Jakarta: PT. Cita Putra Bangsa. 
Kuncoro, Mudrajad. 2003, Metode Riset Untuk Bisnis Dan Ekonomi, Jakarta: Erlangga.

Mufraini, Arief. 2008, Akuntansi \& Manajemen Zakat, Jakarta: Kencana Prenada Media Group.

Saqib, Sayyid. 1978, Fikih Sunnah, Bandung: PT. Alma'arif.

Sudewo, Eri. 2004, Manajemen Zakat, Jakarta: Institut Manajemen Zakat.

Umar, Husein. 2002, Metodelogi Penelitian, Aplikasi Dalam Pemasaran, Jakarta : Erlangga.

Utami, Suci Sedya. 2015, Kontribusi Sosial Kelompok MAsyarakat Dalam Kegiatan Citizen Journalism, Skripsi, Serang: Universitas Sultan Ageng Tirtayasa.

http://www.baznaskota.Bogor@baznas.or. id

http://bazpamekasan.blogspot.com/2011/ 02/uraian-tugas-pengurus-badanamil-zakat.html 